\title{
SEXUAL DIMORPHISM IN THE SUBMAXILLARY GLAND OF THE PIG
}

\author{
W. D. BOOTH, MARY F. HAY AND H. M. DOTT \\ A.R.C. Unit of Reproductive Physiology and Biochemistry, \\ University of Cambridge*
}

(Received 2nd November 1972)

A biochemical sexual dimorphism exists in the submaxillary gland of the pig. Patterson (1968) identified $5 \alpha$-androst-16-en- $3 \alpha-o$ and $5 \alpha$-androst-16-en-3-one in the submaxillary gland of boars but found none in the female pig. Booth (1972) isolated testosterone and $5 \alpha$-dihydrotestosterone from the submaxillary glands of boars only. These observations suggest that the submaxillary gland of the boar, like that of the male mouse (Berkman \& Kronman, 1970), may be a target organ for androgen. In the mouse, hypertrophy of the granular serous tubules in the submaxillary gland is known to occur under the influence of androgen (Berkman \& Kronman, 1970) and the possibility that a similar situation might exist in the pig was therefore examined. In addition, the activity of $\Delta^{5}-3 \beta$-hydroxysteroid dehydrogenase in the gland was studied histochemically.

Submaxillary glands were removed from nineteen Large White $\mathrm{X}$ Essex pigs of different ages, and weighed within $30 \mathrm{~min}$ of slaughter (see Table 1). Samples were fixed in Bouin's fluid for histology; paraffin-wax-embedded sections were stained with either Delafield's haematoxylin and chromotrope $2 \mathrm{R}$ or with Alcian blue in combination with chlorantine fast-red (Culling, 1963). Additional samples were taken from two boars aged 3 months, two castrate boars aged 9 to 12 months, two female pigs aged 9 to 12 months and two boars aged 2 years. These samples were embedded in Tissue-Tek (Ames Company, Stoke Poges, Bucks.) and frozen over solid $\mathrm{CO}_{2}$ for histochemical study. A few samples taken from the boar parotid gland were similarly treated. The histochemical method used for the demonstration of $\Delta^{5}-3 \beta$-hydroxysteroid dehydrogenase was that of Wattenberg (1958). Frozen sections, $16 \mu \mathrm{m}$ thick, which had been mounted on cover-slips, were washed with cold acetone followed by phosphate-buffered saline, $\mathrm{pH} 7 \cdot 3$, and subsequently incubated at $37^{\circ} \mathrm{C}$ for 3 to $4 \mathrm{hr}$ in a medium containing dehydroepiandrosterone $(0.3 \mathrm{mg} / \mathrm{ml})$, nicotinamide-adenine dinucleotide (NAD, $6 \mathrm{mg} / \mathrm{ml}$ ), and nitro blue tetrazolium $(0.4 \mathrm{mg} / \mathrm{ml}) ;$ redistilled acetone was used as a solvent for the steroid. One group of control sections was incubated in medium from which the dehydroepiandrosterone was omitted; in such preparations, the reaction was consistently negative. A second group of control sections was incubated for $30 \mathrm{~min}$ in medium which had neither the steroid substrate nor NAD but to which

* Postal address: Animal Research Station, 307 Huntingdon Road, Cambridge GB3 0JQ, U.K. 
$\mathrm{NADH}_{2}(3 \mathrm{mg} / \mathrm{ml})$ was added in order to confirm the presence of NADtetrazolium reductase (diaphorase); this enzyme is known to be widely distributed in tissues. Further details of the histochemical procedures were given by Deane, Hay, Moor, Rowson \& Short (1966).

Of the two histological procedures used, the Alcian blue method gave a clearer distinction between the acinar serous cells and the mucous cells than the haematoxylin-chromatrope method. With Alcian blue, the mucous cells stained blue, their flattened nuclei being localized near the edge of the cells; the serous cells on the other hand remained virtually unstained and their nuclei were round in appearance (Pl. 1, Fig. 1). Because there appeared to be a variation in the relative proportion of serous and mucous cells in the submaxillary glands of different animals (PI. 1, Figs 1 to 4), an Imanco image

Table 1. Morphological parameters in the submaxillary glands of pigs

\begin{tabular}{|c|c|c|c|c|c|}
\hline Age & Sex & $\begin{array}{l}\text { No. of } \\
\text { animals }\end{array}$ & $\begin{array}{l}\text { Weight in } g \text { of } \\
\text { submaxillary glands } \\
(\text { mean } \pm \text { S.D. })\end{array}$ & $\begin{array}{c}\% \text { Serous cells } \\
(\text { mean } \pm \text { S.D. })\end{array}$ & $\begin{array}{c}\Delta-3^{5} \beta \text {-hydroxy- } \\
\text { steroid dehydrogenase } \\
\text { activity in serous cells }\end{array}$ \\
\hline $\begin{array}{l}12 \text { weeks } \\
18 \text { weeks } \\
24 \text { weeks } \\
30 \text { weeks } \\
9 \text { to } 12 \text { months } \\
9 \text { to } 12 \text { months }\end{array}$ & \begin{tabular}{l} 
Male \\
Male \\
Male \\
Male \\
Male \\
Castrate \\
\multicolumn{1}{c}{ male }
\end{tabular} & $\begin{array}{l}2 \\
2 \\
2 \\
2 \\
2 \\
2\end{array}$ & $\begin{array}{l}11 \cdot 7 \pm 0 \cdot 7 \\
24 \cdot 9 \pm 2 \cdot 4 \\
34 \cdot 0 \pm 2 \cdot 0 \\
51 \cdot 8 \pm 8 \cdot 7 \\
69 \cdot 0 \pm 1 \cdot 2 \\
39 \cdot 0 \pm 9 \cdot 7\end{array}$ & $\begin{array}{l}44 \cdot 4 \pm 1 \cdot 6 \\
50 \cdot 0 \pm 0 \cdot 0 \\
61 \cdot 0 \pm 3 \cdot 8 \\
66 \cdot 9 \pm 1 \cdot 5 \\
65 \cdot 5 \pm 4 \cdot 4 \\
33 \cdot 7 \pm 0.3\end{array}$ & $\begin{array}{c}++ \\
* \\
* \\
* \\
* \\
+\end{array}$ \\
\hline $\begin{array}{l}9 \text { to } 12 \text { months } \\
2 \text { years } \\
10 \text { years }\end{array}$ & $\begin{array}{l}\text { Female } \\
\text { Male } \\
\text { Male }\end{array}$ & $\begin{array}{l}4 \\
2 \\
1\end{array}$ & $\begin{array}{l}31 \cdot 5 \pm 7 \cdot 9 \\
277 \pm 44 \cdot 7 \\
370\end{array}$ & $\begin{array}{l}37 \cdot 4 \pm 4 \cdot 4 \\
69 \cdot 1 \pm 12 \cdot 7 \\
69 \cdot 1\end{array}$ & $\stackrel{+}{+}+$ \\
\hline
\end{tabular}

$\Delta^{5}-3 \beta$-hydroxysteroid dehydrogenase activity: +++ , strong; ++ , moderate; + , weak.

* No histochemical observations made.

analysing computer (Quantimet 720) was employed for the purpose of histometric analysis. The instrument was programmed so as to measure the relative areas occupied by the serous cells and the mucous cells; fields were selected in such a way as to exclude from measurements tissues other than the acini. As Table 1 shows, there was an increase in the weight of the boar submaxillary gland during puberty and a parallel increase in the area occupied by serous cells relative to the area occupied by mucous cells. In post-pubertal 9- to 12-month-old boars, both the weight of the submaxillary glands and the relative area occupied by the serous cells was greater than that found in either the female pigs or in castrate boars of comparable age. In 2-year-old fully mature boars, the gland weights were two to five times heavier than those of the 9- to

\section{EXPLANATION OF PLATE 1}

Paraffin-wax-embedded sections of the submaxillary gland of pigs showing the relative abundance of serous cells $(\mathrm{s})$ and mucous cells $(\mathrm{m})$. Alcian blue and chlorantine fastred. $\times 250$.

Fic. 1. Mature boar, note dominance of serous cells.

FIG. 2. Immature boar, note dominance of mucous cells.

Fig. 3. Ciastrate boar, note doninance of mucous cells.

Fis. 4. Female pig, note dominance of mucous cells. 

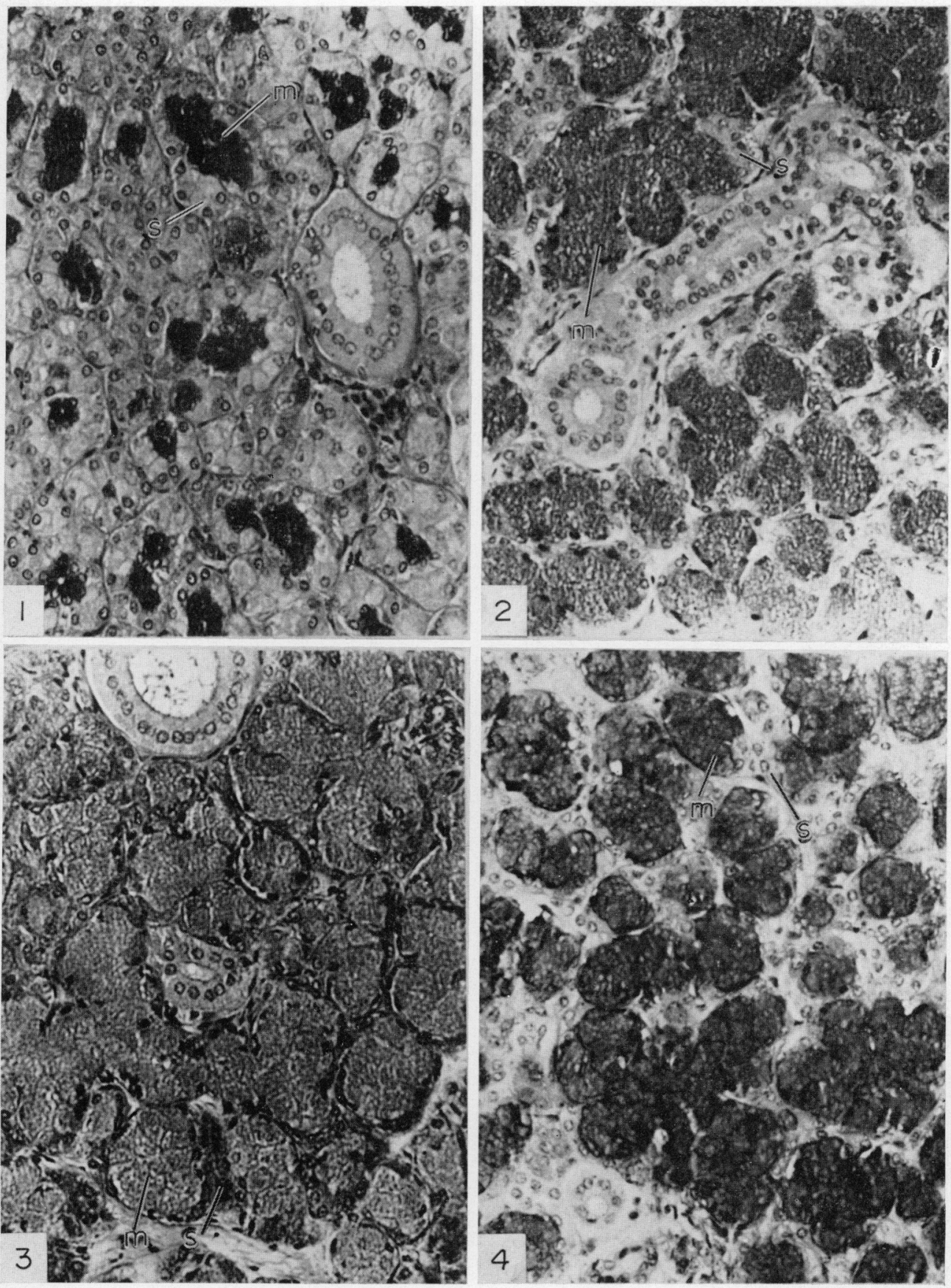

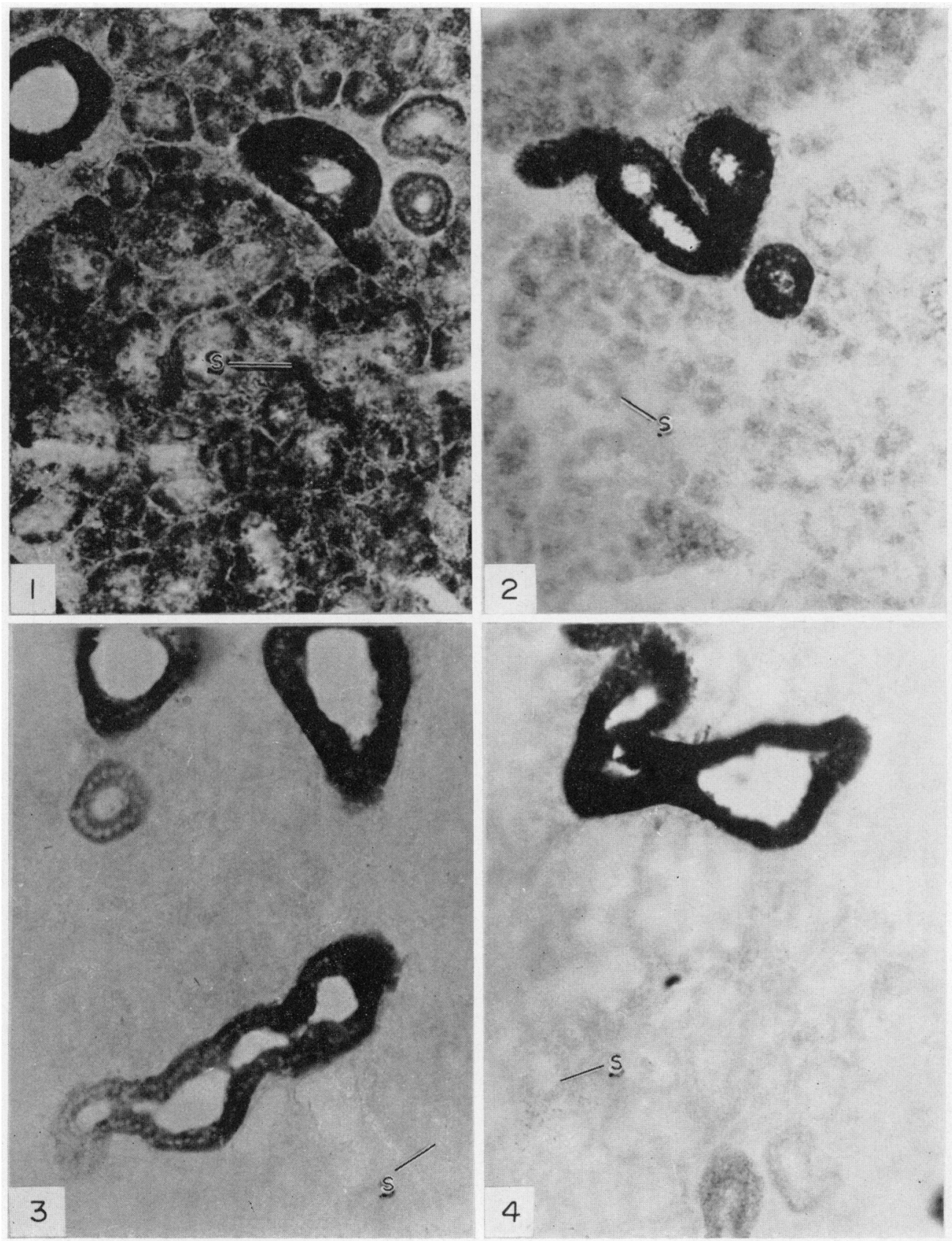
12-month-old boars, and the serous cells predominated. It is relevant to note here that in two pubertal boars, the submaxillary gland was one ninth the weight of the parotid gland but in three fully mature boars, the submaxillary gland was half the weight of the parotid gland.

The histochemically demonstrable activity of $\Delta^{5}-3 \beta$-hydroxysteroid dehydrogenase was intense in the duct system of the submaxillary glands of all pigs (Pl. 2, Figs I to 4) in agreement with the observation of Flood (1973). In the serous cells of the 2-year-old boars, a strong reaction was seen and in the immature boars, a moderate reaction, but in the castrated boars and the female pigs, only a slight reaction was seen (Pl. 2, Figs 1 to 4 ). The serous acini of the boar parotid glands showed virtually no enzyme activity. The strong $\Delta^{5}-3 \beta$ hydroxysteroid dehydrogenase activity exhibited by the serous cells of the submaxillary gland in the mature boar suggests that these cells are involved in androgen metabolism. On the other hand, the activity which is found in the duct system of the gland in both sexes can perhaps be taken as an expression of a general response to anabolic steroids in that tissue in connection with the formation of saliva.

Dehydroepiandrosterone and 5-androstenediol produced by the boar testes (Booth, 1970; Raeside \& Howells, 1971) may be important precursors for the testosterone which is found in the boar submaxillary gland. The greater involvement of the submaxillary gland compared with the parotid gland in androgen and 16-unsaturated $\mathrm{C}_{19}$ steroid metabolism (Katkov, Booth \& Gower, 1972) can be related to the morphological and histochemical differences between the two glands. Differences of a similar kind have been noted by Berkman \& Kronman (1970) in the mouse salivary glands. The sexual dimorphism observed in the submaxillary gland of the pig has probably evolved to allow the release of 16-unsaturated $\mathrm{C}_{19}$ steroids from the boar so that they can act as pheromones to induce the oestrous female pig to adopt the mating stance (Melrose, Reed \& Patterson, 1971).

The authors are indebted to Mrs Kay Levinson for her able technical assistance, and to Dr C. Polge for his valuable suggestions.

\section{REFERENCES}

Berkman, M. D. \& Kronman, J. H. (1970) A histochemical study of the effects of castration and testosterone administration on the major salivary glands of Swiss mice. Acta anat. 76, 200.

Воотн, W. D. (1970) The occurrence of some $\mathrm{G}_{19}$ steroids and vitamin $\mathrm{A}$ in boar testis. $\mathcal{F}$. Reprod. Fert. 23, 533.

Воотн, W. D. (1972) The occurrence of testosterone and $5 \alpha$-dihydrotestosterone in the submaxillary gland of the boar. F. Endocr. 55, 119.

\section{EXPLANATION OF PLATE 2}

Frozen sections showing $\Delta^{5}-3 \beta$-hydroxysteroid dehydrogenase activity in the submaxillary gland of pigs. $\times 160$.

FIG. 5. Mature boar, activity intense in ducts and strong in serous cells (s).

Fig. 6. Immature boar, activity intense in ducts and moderate in serous cells (s).

FIG. 7. Castrate boar, activity intense in ducts and weak in serous cells (s).

Fig. 8. Female pig, similar to castrate boar. 
Culling, G. F. A. (1963) Handbook of histopathological techniques, 2nd edn, p. 251. Butterworths, London.

Deane, H. W., Hay, M. F., Moor, R. M., Rowson, L. E. A. \& Short, R. V. (1966) The corpus luteum of the sheep; relationships between morphology and function during the oestrous cycle. Acta endocr., Copenh. 51, 245.

Flood, P. F. (1973) Histochemical localization of hydroxysteroid dehydrogenases in the maxillary glands of pigs. 7. Reprod. Fert. 32, 125.

Katkov, T., Booth, W. D. \& Gower, D. B. (1972) The metabolism of 16-androstenes in boar salivary glands. Biochim. biophys. Acta, 270, 546.

Melrose, D. R., Reed, H. G. B. \& Patterson, R. L. S. (1971) Androgen steroids associated with boar odour as an aid to the detection of oestrus in pig artificial insemination. Br. vet. $\mathbf{7} .127,497$.

Patterson, R. L. S. (1968) Identification of $3 \alpha$-hydroxy-5 $\alpha$-androst-16-ene as the musk odour component of boar submaxillary taint in pork meat. F. Sci. Fd Agric. 19, 434.

Raeside, J. I. \& Howells, G. A. (1971) The isolation and identification of androstenediol sulfate from spermatic vein blood and testes of the boar. Can. J. Biochem. 49, 80.

Wattenberg, L. W. (1958) Microscopic histochemical demonstration of steroid-3 $\beta$-ol dehydrogenase in tissue sections. J. Histochem. Cytochem. 6, 225. 